\title{
Efikasi Diri dan Motivasi: sebagai Mediasi Pengaruh Pendidikan Kewirausahaan terhadap Minat Berwirausaha
}

\author{
Mega Silvia Karen Hapuk \\ e-mail:megasilvia@upi.edu \\ Suwatno \\ e-mail: suwatno@upi.edu \\ Amir Machmud \\ e-mail: amir@upi.edu \\ (Program Studi Pendidikan Ekonomi, Sekolah Pascasarjana, Universitas Pendidikan Indonesia, Jawa Barat)
}

\begin{abstract}
ABSTRAK: Penelitian ini bertujuan untuk mengetahui dan menganalisis efek mediasi efikasi diri dan motivasi pada pengaruh pendidikan kewirausahaan terhadap minat berwirausaha peserta didik. Metode yang digunakan dalam penelitian ini merupakan penelitian survey eksplanatori dengan teknik pengumpulan data melalui angket dan observasi. Populasi penelitian ini adalah seluruh peserta didik kelas XI angkatan 2018 /2019 sebanyak 7.913 peserta didik sedangkan berdasarkan perhitungan Slovin sampel penelitian ini sebanyak 400 peserta didik. Data yang telah terkumpul kemudian dianalisis menggunakan teknik analisis deskriptif dan regresi linier berganda dengan Moderat Regression Analysis (MRA). Hasil penelitian menunjukkan bahwa: 1) tingkat efikasi diri, motivasi dan minat berwirausaha peserta didik berada pada kategori sangat tinggi. 2) pendidikan kewirausahaan berpengaruh terhadap minat berwirausaha peserta didik. 3) efikasi diri dan motivasi memediasi pengaruh pendidikan kewirausahaan terhadap minat berwirausaha peserta didik. Temuan ini mengindikasikan bahwa untuk meningkatkan minat berwirausaha, maka dalam proses pembelajaran di SMK perlu ditekankan pada upaya peningkatan efikasi diri dan motivasi.
\end{abstract}

Kata kunci - Efikasi diri, motivasi, pendidikan kewirausahaan, minat berwirausaha.

ABSTRACT : This research is motivated by the low entrepreneurial intention of Vocational High School (VHG) students in Bandung. This study aims to determine and analyze the mediating effects of self-efficacy and motivation on the effect of entrepreneurship education on students' entrepreneurial interest. The method used in this study is an explanatory survey research with data collection techniques through questionnaires and observations. The population of this study were all students of class XI class 2018/2019 as many as 7,913 students, while based on Slovin calculations the sample of this study was 400 students. The collected data were then analyzed using descriptive analysis techniques and multiple linear regression with Moderate Regression Analysis (MRA). The results showed that: 1) the level of self-efficacy, motivation and interest in entrepreneurship of students were in the very high category. 2) entrepreneurship education affects the entrepreneurial interest of students. 3) self-efficacy and motivation mediate the effect of entrepreneurship education on students' entrepreneurial interest. These findings indicate that to increase interest in entrepreneurship, the learning process in SMK needs to be emphasized on efforts to increase self-efficacy and motivation.

Keywords - Self-efficacy, motivation, entrepreneurship education, entrepreneurial intention. 


\section{PENDAHULUAN}

Masalah kewirausahaan beberapa tahun terakhir menjadi masalah penting yang dibahas dalam lembaga-lembaga ekonomi mulai dari tingkat daerah, nasional, bahkan internasional. Kewirausahaan menjadi penting karena mengarah pada peningkatan efisiensi ekonomi, membawa inovasi ke pasar, menciptakan pekerjaan baru, dan mempertahankan tingkat pekerjaan (Carree \& Thurik, 2010). Kewirausahaan sering dikaitkan untuk mendorong pertumbuhan ekonomi, inovasi, pekerjaan dan kreasi usaha. Penelitian empiris juga mendukung hubungan positif antara aktivitas kewirausahaan terhadap pertumbuhan ekonomi. Kecenderungan ini karena keyakinan bahwa kewirausahaan adalah kunci untuk sejumlah hasil-hasil sosial yang diinginkan, termasuk pertumbuhan ekonomi, pengangguran yang lebih rendah, dan modernisasi teknologi (Firdaus, 2014; Lumpkin, Steier, \& Wright, 2011)

Minat merupakan sikap terhadap wirausaha. Minat ini juga nenunjukkan arah pembentukkan wirausaha daripada menjadi pekerja organisasi (karyawan). Minat kewirausahaan sangat penting untuk memahami proses kewirausahaan, karena minat selalu mendahului pada setiap upaya dalam perilaku kewirausahaan (Schweizer, Vahlne, \& Johanson, 2010). Minat kewirausahaan merupakan langkah awal dari suatu proses pendirian sebuah usaha yang umumnya bersifat jangka panjang (Wang \& Wong, 2004). Jadi minat kewirausahan sangat perlu untuk dilatih dan dikembangkan mengingatkan bahwa awal dari terjadinya aksi berwirausaha dimulai dari adanya minat terlebih dahulu.

Pendidikan kewirausahaan merupakan faktor penting yang dapat membantu peserta didik mempersepsikan keinginan dan harapan untuk menjadi wirausahawan melalui proses kognitif (Wang \& Wong, 2004). Pengetahuan sebagai hasil dari proses pendidikan pada aspek kognitif, berperan penting dalam memunculkan dan mengembangkan proses dari kewirausahaan. Peningkatan minat berwirausaha pada peserta didik berdampak positif terhadap perkembangan perekonomian melalui perubahan pola pikir dari mencari kerja menjadi pencipta lapangan pekerjaan sehingga mengurangi tingkat pengangguran. Minat berwirausaha tidak sekedar lahir secara natural, tetapi juga dapat diciptakan (Business, 2015).

Institusi pendidikan memegang peran penting dalam membangun kompetensi awal wirausaha yang yang kemudian dimanifestasikan dalam bentuk kegiatan wirausaha. Penelitian menunjukkan bahwa institusi pendidikan sebagaimana anggota didalamnya yang terlibat didalam aktivitas wirausaha memainkan peran penting dalam membanggun minat berwirausaha diantara peserta didik melalui program-program inovatif dan orientasi budaya (Ismail et al., 2015). Penelitian terdahulu di tahun 2010 menunjukkan kurangnya kemampuan peserta didik di Cina dalam mengidentifikasi dan merebut kesempatan memulai bisnis, mereka lebih memperhatikan dampak dari keberadaan kesempatan pada kelayakan memulai bisnis dibandingkan peserta didik di USA (Wang, Lu \& Millington, 2011). Selanjutnya penelitian (Armstrong, n.d.,2014) menunjukkan bahwa rendahnya minat berwirausaha di Asia, tidak hanya diakibatkan oleh pendidikan kewirausahaan dan pelatihan-pelatihan yang kurang efektif, namun juga faktor sosial budaya. 
Sebagian besar studi empiris yang disurvei menunjukkan bahwa kewirausahaan dapat diajarkan, atau setidaknya didukung, oleh pendidikan kewirausahaan (Rachmadyanti \& Wicaksono, 2017). Pendidikan kewirausahaan menjadi faktor penting dalam menumbuhkan dan mengembangkan keinginan, jiwa dan prilaku berwirausaha dikalangan generasi muda karena pendidikan merupakan sumber sikap dan minat keseluruhan untuk menjadi wirausahawan sukses di masa depan (Indriyatni, 2013). Minat berwirausaha perlu untuk menggali potensi sebelum menjalankan usaha. Terbentuknya intensi dapat diterangkan dengan teori perilaku terencana yang mengasumsikan manusia selalu mempunyai tujuan dalam berperilaku.

Selain pendidikan kewirausaha, efikasi diri juga merupakn faktor internal yang mempengaruhi minat berwirausaha. Efikasi diri adalah keyakinan pribadi pada kemampuan diri untuk mengatur dan melaksanakan tindakan yang diperlukan sehingga mencapai kemampuan yang ditentukan (Bandura, 2006). Banyaknya masyarakat yang semakin sulit untuk menemukan lapangan pekerjaan pada masa kini menimbulkan banyak sekali pengangguran khususnya di Indonesia. Jumlah saing para pencari kerja yang banyak tidak sebanding dengan ketatnya dalam seleksi pekerjaan yang terbatas (Keputusan, Dengan, \& Dewi, 2017). Bahkan orang-orang yang bergelar sarjana pun sekarang ini bukan menjadi jaminan untuk mendapatkan pekerjaan yang sesuai dengan degree mereka. Dampaknya adalah banyak para pelamar kerja yang mendapat suatu pekerjaan yang tidak sesuai dengan pendidikan mereka, mendapatkan pekerjaan yang tidak layak, atau bahkan akan menjadi pengangguran yang tentunya sangat ditakuti oleh para pencari kerja (Darmastuti, 2012).

Selain kedua faktor di atas, faktor motivasi berpengaruh dengan timbulnya minat berwirausaha seseorang dalam mengambil tindakan atau mencapai tujuan (Mahesa \& Rahardja, 2012). Dalam penelitian ini kerangka teoritisnya menggambarkan tentang pengaruh dari pendidikan kewirausahaan, motivasi dan efikasi diri peserta didik untuk berwirausaha terhadap minat berwirausaha. Permasalahan yang dihadapi oleh Negara berkembang khususnya tingkat wirausaha yang masih rendah seperti yang terjadi di Indonesia menyebabkan peneliti tertarik untuk mengangkat hal tersebut. Salah satu faktor yang mempengaruhi minat berwirausaha yaitu harapan pendapatan yang tinggi, dukungan dari lingkungan, motivasi keluarga, dan pendidikan kewirausahaan yang diterima. Indikator yang digunakan meliputi tidak ketergantungan pada orang lain (mandiri), membantu lingkungan social dan perasaan senang menjadi seorang wirausaha. Faktor pendorong pertumbuhan kewirausahaan seseorang untuk berwirausaha yaitu laba (laba atau pendapatan yang tinggi sesuai harapan yang dikehendaki seseorang), bebas mengatur semua pekerjaan, impian personal dan kemandirian (Wedayanti \& Giantari, 2016).

Penelitian mengenai hubungan efikasi diri, motivasi, pendidikan kewirausahaan dan minat berwirausaha sudah banyak diteliti sebelumnya (Ayu, Anggraeni, \& Nurcaya, 2016; Fayolle \& Gailly, 2015; Wedayanti \& Giantari, 2016). Penelitian sebelumnya pada umumnya hanya menjelaskan dua variabel, belum seluruh variabel dikaji secara bersama-sama. Untuk itu penelitian ini dilakukan untuk mengetahui dan menganalisis efek mediasi efikasi diri dan motivasi pada pengaruh pendidikan kewirausahaan terhadap minat berwirausaha peserta didik. 


\section{TINJAUAN PUSTAKA}

\section{Minat Berwirausaha}

Theory of Planned Behavior ( TPB ) Ajzen, 1991 menyatakan bahwa minat (intensi) seseorang untuk melakukan suatu perilaku, minat merupakan variabel antara yang menyebabkan terjadinya perilaku dari suatu sikap maupun variabel lainnya. Minat berwirausaha adalah dorongan dari dalam seseorang yang mampu memberikan semangat untuk melakukan kegiatan bisnis untuk mendapatkan penghasilan tanpa tergantung pada orang lain. Minat telah terbukti menjadi yang terbaik bagi perilaku kewirausahaan (Adekiya \& Ibrahim, 2016). Berdasarkan teori dan pendapat di atas, maka dapat dinyatakan bahwa minat berwirausaha adalah suatu ketertarikan pada suatu hal atau aktivitas yang menciptakan perasaan keinginan, kewaspadaan, perhatian, dan konsentrasi untuk memiliki bisnis sendiri atau berminat untuk membuat wirausaha sendiri.

Pada dasarnya pembentukan jiwa kewirausahaan dipengaruhi oleh faktor internal dan eksternal, faktor internal yang berasal dari dalam diri wirausaha dapat berupa sifat-sifat personal, sikap, kemauan dan kemampuan individu yang dapat memberi kekuatan individu untuk berwirausaha. Sedangkan faktor eksternal berasal dari luar diri pelaku berwirausaha yang dapat berupa unsur dari lingkungan sekitar seperti lingkungan keluarga, lingkungan dunia usaha, lingkungan fisik, lingkungan sosial ekonomi dan lain-lain (Moraes, Iizuka, \& Pedro, 2018).

Cara menumbuhkan minat berwirausaha dengan memahami cara-cara dimana peserta didik mengungkapkan rasa ingin tahu tentang sifat suatu obyek, fenomena, atau suatu topik tertentu. Minat tidak dibawa individu sejak lahir melainkan diperoleh dari belajar, kemudian minat terhadap sesuatu dipelajari dan dipengaruhi belajar selanjutkan serta mempengaruhi penerimaan minat-minat baru Minat wirausaha adalah gejala psikis untuk memusatkan perhatian dan berbuat sesuatu terhadap wirausaha itu dengan perasaan senang karena membawa manfaat bagi dirinya. Minat berwirausaha merupakan pemusatan perhatian pada wirausaha karena adanya rasa suka dan disertai keinginan mempelajari, mengetahui dan membuktikan lebih lanjut terhadap wirausaha (Che, Mistima, \& Mohd, 2015).

\section{Pendidikan Kewirausahaan}

Pendidikan kewirausahaan sebagai proses menyediakan individu dengan konsep dan keterampilan untuk mengenali peluang yang diabaikan oleh orang lain dan memiliki wawasan dan harga diri untuk bertindak disaat orang lain ragu-ragu. Tujuan dari pendidikan kewirausahaan tercantum dalam standar isi untuk satuan dasar dan menengah yaitu agar peserta didik dapat mengaktualisasikan diri dalam perilaku kewirausahaan. Selain itu, pendidikan kewirausahaan merupakan cara yang efektif untuk mempromosikan dan mengembangkan minat berwirausaha dikalangan siswa (Denanyoh, Adjei, \& Nyemekye, 2015).

Terdapat beberapa bentuk pengetahuan yang harus dimiliki oleh seorang wirausahawan, yaitu: 1) pengetahuan mengenai usaha yang akan dirintis dan pengetahuan akan lingkungan usaha di sekitarnya yang akan mempengaruhi kegiatan wirausaha; 2) pengetahuan tentang peran dan tanggung jawab; 3) pengetahuan tentang kepribadian dan tanggung jawab; 4) pendidikan kewirausahan memiliki peran yang sangat penting dalam kegiatan kewirausahaan. Pendidikan kewirausahaan dapat membentuk pola pikir, sikap, dan perilaku pada mahasiswa ( $\mathrm{O}^{\prime}$ Gorman, Byrne, \& Pandya, 2008).

\section{Efikasi Diri}

Konsep efikasi diri diderivasi dari teori pembelajaran sosial mengambil peran signifikan bagi aksi dan intensi berwirausaha seseorang. Efikasi diri ini merupakan keyakinan bahwa seseorang dapat menguasai suatu situasi dan menghasilkan berbagai hasil positif. Sejalan dengan kedua pendapat diatas, efikasi diri dapat diartikan sebagai keyakinan seseorang bahwa dirinya mampu untuk melakukan tugas akademik yang diberikan dan menendakan level kemampuan dirinya 
(Bandura, 2010). Berdasarkan beberapa definisi diatas, dapat disimpulkan bahwa efikasi diri merupakan keyakinan pada kemampuan yang dimiliki oleh seseorang. Apabila seseorang tidak yakin dapat memproduksi hasil yang mereka inginkan, mereka memiliki sedikit motivasi untuk bertindak.

Pengukuran efikasi diri yang dimiliki seseorang mengacu pada tiga dimensi yaitu magnitude, strenght, generality yang mempunyai implikasi penting dalam performansi yang jelas. Tingkat kesulitan tugas (magnitude) yaitu suatu masalah yang berkaitan dengan derajat kesulitan tugas individu. Kekuatan keyakinan (strenght) yaitu berkaitan dengan kekuatan dalam keyakinan suatu kepercayaan diri yang ada dalam diri seseorang yang dapat ia wujudkan dalam meraih performa tertentu. Terakhir, generalitas (generality) yaitu hal yang berkaitan dengan apakah keyakinan efficacy akan berlangsung dalam domain tertentu atau berlaku dalam berbagai macam aktifitas dan situasi (Zimmerman, 2000).

\section{Motivasi}

Teori motivasi pertama kali dikemukakan oleh Maslow. Ia mengemukakan tentang hierarki kebutuhan yang mendasari motivasi. Menurutnya, kebutuhan manusia bertingkat sesuai dengan tingkatan pemuasannya, yaitu kebutuhan fisik, kebutuhan akan keamanan, kebutuhan sosial, kebutuhan harga diri, dan kebutuhan akan aktualisasi diri. Motivasi adalah dorongan psikologis yang mengarahkan seseorang kearah suatu tujuan. Motivasi membuat keadaan dalam diri individu muncul, terarah, dan mempertahankan perilaku. Motivasi adalah daya pendorong dan keinginan agar terwujud energi pendorong dari dalam agar apapun yang kita inginkan dapat terwujud (Andjarwati, 2015).

Motivasi memiliki peran yang sangat penting sebagai langkah awal yang akan memacu seseorang untuk melakukan suatu tindakan atau aktivitas tertentu. Berikut ini merupakan faktor yang mempengaruhi atau membantu timbulnya motivasi wirausaha: 1) direct job outgrowth yaitu kegiatan dalam pekerjaan pertama, mempengaruhi pilihan terhadap jenis usaha yang dilakukan berikutnya. Contohnya, seseorang karena keperluannya akan fotocopy sangat tinggi, sehingga keadaan tersebut menginsprirasinya untuk membuka usaha foto copy, 2) tangential opportunities yaitu mulainya usaha yang kedua ini tidak ada kaitannya dengan jenis pekerjaan pertama (Lazaric \& Raybaut, 2014).

\section{METODE}

Metode yang digunakan dalam penelitian ini merupakan penelitian survey eksplanatori. Populasi penelitian ini adalah seluruh peserta didik kelas XI angkatan 2018 /2019 SMK Kota Bandung sebanyak 7.913 peserta didik dan sampel dalam penelitian ini adalah sebanyak 400 peserta didik. Berdasarkan jenis kelamin yaitu peserta didik perempuan sebesar $54 \%$ dan peserta didik laki-laki sebesar 46\%. Berdasarkan asal sekolah SMK Negeri 1 Bandung sebesar 13,25\%, SMK Negeri 3 Bandung sebesar 21,75\%, SMK Negeri 5 Bandung sebesar 18,25\%, SMK Negeri 7 Bandung sebesar 15,25\%, SMK Negeri 9 Bandung sebesar 15,25\% dan SMK Negeri 11 Bandung sebesar 16,75\%. Berdasarkan jurusan didominasi oleh jurusan teknologi dan rekayasa sebesar $60 \%$, jurusan seni rupa dan kriya $20 \%$, jurusan bisnis dan manajemen $15 \%$ dan jurusan pariwisata $15 \%$.

Pengukuran tingkat minat berwirausaha peserta didik indikator yang digunakan mengacu pada riset (Shinnar, Pruett, \& Toney, 2009) yaitu preference, desire dan plan. Pengukuran tingkat efikasi diri indikator mengacu pada riset (Bandura, 2010)yaitu magnitude, generality dan strength. Pengukuran tingkat motivasi indaktor mengacu pada riset (Lazaric \& Raybaut, 2014) yaitu need for power, need for achievement dan need for affiliation. Pengukuran pendidikan kewirausahaan indikator mengacu pada riset (Y. A. Samuel., K. Ernest., 2013) yaitu enterprenurial awareness education, education for start-up, education for enterprenurial dynamic dan contrinuining education for enterpernurship. 
Pengumpulan data dilakukan menggunakan kuesioner kemudian dianalisis menggunakan statistika deskriptif dan statistika inferensial. Data yang telah terkumpul dianalisis dengan sistem skoring skala likert 5 poin dari sangat tidak setuju (1) hingga sangat setuju (5) untuk mendapatkan data interval dan diberi skor atau nilai. Instrumen penelitian diuji melalui uji validitas dan uji realibitas. Pengujian hipotesis dilakukan dengan regresi berganda Moderat Regression Analysis (MRA) dikarenakan untuk mengetahui besarnya pengaruh variable mediasi yaitu motivasi dan efikasi diri pada pengaruh pendidikan kewirausahaan terhadap minat berwirausaha.

\section{PEMBAHASAN}

\section{Gambaran Umum Efikasi Diri, Motivasi, Pendidikan Kewirausahaan dan Minat Berwirausaha}

Tingkat minat berwirausaha dalam penelitian ini merupakan variabel terikat sedangkan efikasi diri, motivasi dan pendidikan kewirausahan merupakan variabel tidak terikat. Hasil diperoleh berdasarkan keseluruhan dimensi minat berwirausaha yang terdiri dari 3 dimensi, efikasi diri terdiri dari 3 dimensi, motivasi terdiri dari 3 dimensi dan pendidikan kewirausahaan terdiri dari 4 dimensi. Secara rinci, skor setiap variabel dapat dilihat pada Tabel 1.

Tabel 1.

Rekapitulasi Tingkat Minat Berwirausaha, Efikasi Diri, Motivasi dan Pendidikan Kewirausahaan

\begin{tabular}{|c|c|c|c|c|c|}
\hline \multirow[t]{2}{*}{ No. } & \multirow[t]{2}{*}{ Dimensi } & \multicolumn{3}{|c|}{ \% Frekuensi Skor } & \multirow{2}{*}{$\begin{array}{l}\text { Capaian } \\
\text { Kriteria }\end{array}$} \\
\hline & & 2 & 3 & 4 & \\
\hline \multicolumn{6}{|c|}{ Tingkat Minat Berwirausaha } \\
\hline 1 & Preference & 38,76 & & 61,24 & $\begin{array}{c}\text { Cenderung } \\
\text { Tinggi }\end{array}$ \\
\hline 2 & Desire & 44,86 & & 55,14 & $\begin{array}{c}\text { Cenderung } \\
\text { Tinggi }\end{array}$ \\
\hline 3 & Plan & 21,88 & & 78,12 & $\begin{array}{c}\text { Cenderung } \\
\text { Tinggi }\end{array}$ \\
\hline \multicolumn{6}{|c|}{ Tingkat Efikasi Diri } \\
\hline 1 & Magnitude & 41,60 & & 58,40 & $\begin{array}{c}\text { Cenderung } \\
\text { Tinggi }\end{array}$ \\
\hline 2 & Generality & 45,60 & & 54,40 & $\begin{array}{c}\text { Cenderung } \\
\text { Tinggi }\end{array}$ \\
\hline 3 & Strength & 38,30 & & 61,70 & $\begin{array}{c}\text { Cenderung } \\
\text { Tinggi } \\
\end{array}$ \\
\hline \multicolumn{6}{|c|}{ Tingkat Motivasi } \\
\hline & Need for Power & 35,00 & & 65,00 & $\begin{array}{c}\text { Cenderung } \\
\text { Tinggi }\end{array}$ \\
\hline & Need for Achievement & 38,90 & & 61,10 & $\begin{array}{c}\text { Cenderung } \\
\text { Tinggi }\end{array}$ \\
\hline 3 & Need for Affiliation & 32,20 & & 67,80 & $\begin{array}{c}\text { Cenderung } \\
\text { Tinggi }\end{array}$ \\
\hline \multicolumn{6}{|c|}{ Tingkat Pendidikan Kewirausahaan } \\
\hline 1 & Enterprenurial Awareness Education & 41,60 & & 58,40 & $\begin{array}{c}\text { Cenderung } \\
\text { Tinggi }\end{array}$ \\
\hline 2 & Education for Start-Up & 37,80 & & 62,60 & $\begin{array}{c}\text { Cenderung } \\
\text { Tinggi }\end{array}$ \\
\hline 3 & Education for Enterprenurial Dynamic & 37,30 & & 62,30 & $\begin{array}{c}\text { Cenderung } \\
\text { Tinggi }\end{array}$ \\
\hline 4 & Contrinuining Education for Enterpernurship & 43,30 & & 56,70 & $\begin{array}{c}\text { Cenderung } \\
\text { Tinggi }\end{array}$ \\
\hline
\end{tabular}

Sumber: Hasil Pengolahan Data, 2020

Berdasarkan Tabel 1 tingkat minat berwirausaha peserta didik berada pada kategori kecenderungan tinggi. Kategori sangat tinggi ini artinya peserta didik memiliki 1) preference, merupakan sejauh mana seseorang memilih wirausaha sebagai pilihan karir dimasa yang akan 
datang dibanding memilih karir sebagai pekerja. 2) desire, merupakan keinginan individu untuk mandiri dan membuka usaha dimasa yang akan datang, dan 3) plan, merupakan keseriusan berpikir dan perencanaan mengenai pembukaan usaha baru.

Tingkat efikasi diri peserta didik berada pada kategori kecenderungan tinggi. Kategori tinggi ini artinya peserta didik memiliki 1) yakin dapat menyelesaikan tugas tertentu. 2) yakin dalam memotivasi diri untuk melakukan tindakan yang diperlukan dalam menyelesaikan tuga. 3) yakin bahwa diri mampu keras, gigih dan tekun. 3) yakin diri mampu menghadapi hambatan dan bertahan dalam kesulitan, dan 4) yakin bahwa peserta didik dapat tugas apapun yang memiliki tingkat kesulitan paling tinggi.

Tingkat motivasi diri peserta didik berada pada kategori kecenderungan tinggi. Kategori tinggi artinya peserta didik memiliki 1) need for power yaitu kebutuhan untuk membuat orang berperilaku dalam keadaan yang wajar dan bijaksana didalam tugasnya masing-masing, atau mampu memberi pengaruh kepadaorang lain. 2) need for achievement yaitu kemampuan untuk mencapai hubungan kepada standar perusahaan yang telah ditentukan juga perjuangan karyawan untuk menuju keberhasilan, dan ) need for affiliation yaitu hasrat untuk bersahabat dan mengenal lebih dekat rekan kerja atau para karyawan didalam organisasi, atau selalu bergabung dengan kelompok bersamasama orang lain.

Tingkat pendidikan kewirausahaan peserta didik berada pada kategori kecenderungan tinggi. Kategori tinggi artinya pendidikan wirausaha telah 1) entrepreneurial awareness education yaitu pendidikan kewirausahaan yang menekankan pada keinginan dan minat. 2) education for start-up yaitu pendidikan kewirausahaan yang mengacu pada kesiapan bisnis. 3) education for entrepreneurial dynamic yaitu pendidikan kewirausahaan yang mampu mempromosikan perilaku kewirausahaan yang dinamis, dan 4) contrinuining education for entrepreneurship yaitu pendidikan kewirausahaan sebagai upaya meningkatkan kemampuan yang telah ada.

\section{Hasil Pengujian Statistik MRA}

Instrumen yang digunakan dalam penelitian ini sudah di uji validitas dan uji reabilitas. Berdasarkan hasil uji validitas semua item pernyataan valid dan dapat digunakan. Selain itu berdasarkan hasil uji reabilitas juga, semua item pernyataan dinyatakan reliabel. Pengujian validitas dan reabilitas ini menggunakan bantuan program SPSS 22 for windows.

Selanjutnya, berdasarkan hasil pengolahan dan analisis data diperoleh model koefisien regresi variabel X terhadap Y pada Tabel 2 berikut ini:

Tabel 2. Model Koefisien Regresi Variabel X terhadap Y

\begin{tabular}{cccccrrr}
\hline Model & $\mathrm{R}$ & $\mathrm{R}$ & $\mathrm{R}$ & $\begin{array}{c}\text { Std. } \\
\text { Eror }\end{array}$ & Beta & $\begin{array}{c}(\mathrm{F}) \\
\mathrm{t}\end{array}$ & $\mathrm{P}$ \\
\hline Model 1 & 0.523 & 0.514 & & & & $(165.425)$ & \\
\hline Constant & & & 15.214 & 1.823 & & 7.436 & 0.000 \\
\hline Pendidikan & & & 0.542 & 0.037 & 0.526 & 12.376 & 0.000
\end{tabular}

Kewirausahaan

$(\mathrm{X})$

Sumber : Hasil Pengolahan Data, 2020

Berdasarkan Tabel 2 diatas, dapat diketahui koefisien determinasi $\left(\mathrm{R}^{2}\right)$ dalam penelitian ini digunakan untuk melihat besarnya pengaruh secara bersama-sama variabel eksogen dalam model yang dianalisis. Berdasarkan hasil di atas, dapat diketahui bahwa hasil perhitungan $\mathrm{R}^{2}$ sebesar 0.514 , artinya bahwa variabel pendidikan kewirausahaan berpengaruh terhadap variabel minat berwirausaha sebesar $51,40 \%$ dan sisanya $48,60 \%$ dipengaruhi oleh variabel lain yang tidak diteliti dalam penelitian ini. 
Selanjutnya, analisis persamaan regresi 2 ini bertujuan untuk mengetahui efek mediasi efikasi diri antara pendidikan kewirausahaan terhadap minat berwirausaha. Berdasarkan hasil pengolahan data diperoleh model koefisien regresi variabel M1 antara X terhadap Y pada Tabel 3 berikut ini:

Tabel 3. Model Koefisien Regresi Variabel M1 antara X terhadap $Y$

\begin{tabular}{|c|c|c|c|c|c|c|c|c|}
\hline Model & $\begin{array}{l}\mathrm{R} \\
(\mathrm{p})\end{array}$ & $\begin{array}{c}\mathrm{R}^{2} \\
\text { (Adjusted } \\
\mathrm{R}^{2} \text { ) }\end{array}$ & $\begin{array}{c}\mathrm{R}^{2} \\
\text { Change } \\
(\mathrm{p})\end{array}$ & B & $\begin{array}{l}\text { Std. } \\
\text { Eror }\end{array}$ & Beta & $\begin{array}{l}(\mathrm{F}) \\
\mathrm{T}\end{array}$ & $\mathrm{P}$ \\
\hline Model 1 & $\begin{array}{r}0.541 \\
(0.000)\end{array}$ & $\begin{array}{r}0.541 \\
(0.530)\end{array}$ & $\begin{array}{r}0.471 \\
(0.000)\end{array}$ & & & & $(106.312)$ & \\
\hline Constant & & & & 10.237 & 0.037 & & 5.275 & 0.000 \\
\hline$X$ & & & & 0.415 & 0.048 & 0.493 & 8.811 & 0.000 \\
\hline $\mathrm{M}_{1}$ & & & & 0.426 & 0.059 & 0.259 & 4.585 & 0.000 \\
\hline Model 2 & $\begin{array}{r}0.582 \\
(0.030)\end{array}$ & $\begin{array}{r}0.571 \\
(0.431)\end{array}$ & $\begin{array}{r}0.383 \\
(0.062)\end{array}$ & & & & (114.003) & \\
\hline Constant & & & & 12.472 & 0.472 & & 1.271 & 0.028 \\
\hline$X$ & & & & 0.431 & 0.241 & 0.418 & 2.250 & 0.022 \\
\hline $\mathrm{M}_{1}$ & & & & 0.234 & 0.250 & 0.264 & 1.343 & 0.026 \\
\hline $\mathrm{X}^{*} \mathrm{M}_{1}$ & & & & 0.235 & 0.252 & 0.247 & 1.863 & 0.035 \\
\hline
\end{tabular}

Sumber : Hasil Pengolahan Data, 2020

Berdasarkan Tabel 3 diatas dapat diketahui bahwa Model 1 dengan variabel X berpengaruh signifikan terhadap variabel $\mathrm{Y}$ karena $\mathrm{p}<0,05$ yaitu $0,000<0,05$ dan variabel M1 berpengaruh signifikan terhadap $\mathrm{Y}$ karena $\mathrm{p}<0,05$ yaitu $0,000<0,05$. Model 2 dapat dketahui bahwa setelah adanya interaksi variabel mediasi maka hasil yang diperoleh dapat dinyatakan signifikan yang berarti memediasi hubungan antara $X$ dengan $Y$ karena $p<0,05$ yaitu p sebesar 0,035 . Sehingga, dapat disimpulkan model 2 lebih baik digunakan dalam menjelaskan fenomena $Y$ jika dibandingkan dengan model 1 dan efikasi diri baik untuk digunakan sebagai variabel mediasi.

Selanjutnya, analisis persamaan regresi 2 digunakan untuk mengetahui pengaruh mediasi motivasi antara pendidikan kewirausahaan terhadap minat berwirausaha. Berdasarkan hasil pengolahan dan analisis data diperoleh model koefisien regresi variabel M2 antara X terhadap Y pada Tabel 4 berikut ini:

Tabel 4 Model Koefisien Regresi Variabel M2 antara X terhadap $Y$

\begin{tabular}{|c|c|c|c|c|c|c|c|c|}
\hline Model & $\begin{array}{l}\mathrm{R} \\
(\mathrm{p})\end{array}$ & $\begin{array}{c}\mathrm{R}^{2} \\
\text { (Adjusted } \\
\mathrm{R}^{2} \text { ) }\end{array}$ & $\begin{array}{c}\mathrm{R}^{2} \\
\text { Change } \\
(\mathrm{p})\end{array}$ & B & $\begin{array}{l}\text { Std. } \\
\text { Eror }\end{array}$ & Beta & $\begin{array}{c}(\mathrm{F}) \\
\mathrm{t}\end{array}$ & $\mathrm{P}$ \\
\hline Model 1 & $\begin{array}{r}0.561 \\
(0.000) \\
\end{array}$ & $\begin{array}{r}0.441 \\
(0.452) \\
\end{array}$ & $\begin{array}{r}0.450 \\
(0.000) \\
\end{array}$ & & & & $(106.312)$ & \\
\hline Constant & & & & 11.235 & 0.135 & & 5.154 & 0.000 \\
\hline$X$ & & & & 0.512 & 0.042 & 0.482 & 8.871 & 0.000 \\
\hline $\mathrm{M}_{1}$ & & & & 0.323 & 0.057 & 0.243 & 4.543 & 0.000 \\
\hline Model 2 & $\begin{array}{r}0.583 \\
(0.041) \\
\end{array}$ & $\begin{array}{r}0.451 \\
(0.463) \\
\end{array}$ & $\begin{array}{r}0.481 \\
(0.052) \\
\end{array}$ & & & & $(104.012)$ & \\
\hline Constant & & & & 12.488 & 0.772 & & 1.271 & 0.017 \\
\hline $\mathrm{X}$ & & & & 0.613 & 0.331 & 0.512 & 2.350 & 0.018 \\
\hline $\mathrm{M}_{1}$ & & & & 0.412 & 0.321 & 0.254 & 1.341 & 0.021 \\
\hline$X^{*} \mathrm{M}_{2}$ & & & & 0.213 & 0.314 & 0.213 & 1.882 & 0.050 \\
\hline
\end{tabular}

Sumber : Hasil Pengolahan Data, 2020 
Berdasarkan Tabel 4 diatas dapat dinyatakan bahwa Model 1 dengan variabel $\mathrm{X}$ berpengaruh signifikan terhadap $\mathrm{Y}$ karena $\mathrm{p}<0,05$ yaitu $0,000<0,05$ dan variabel M2 berpengaruh signifikan terhadap $\mathrm{Y}$ karena $\mathrm{p}<0,05$ yaitu $0,000<0,05$. Model 2 menjelaskan bahwa setelah adanya interaksi variabel mediasi maka hasil yang diperoleh dapat dinyatakan signifikan yang berarti memediasi hubungan antara $X$ dengan $Y$ karena $p<0,05$ yaitu $p$ sebesar 0,050 . Sehingga, dapat disimpulkan bahwa model 2 lebih baik untuk digunakan dalam menjelaskan fenomena $\mathrm{Y}$ apabila dibandingkan dengan model 1 dan motivasi baik untuk digunakan sebagai variabel mediasi.

\section{KESIMPULAN}

Berdasarkan hasil pengolahan dan analisis data, maka dapat ditarik kesimpulan bahwa tingkat efikasi diri, motivasi, pendidikan kewirausahaan dan minat berwirausaha berada pada kategori tinggi. Hasil ini menunjukkan bahwa hipotesis pendidikan kewirausahaan memiliki pengaruh positif dan signifikan terhadap minat berwirausaha terbukti benar serta efikasi diri dan motivasi mampu memperkuat hubungan antara keduanya. Hasi ini menunjukkan bahwa pendidikan kewirausahaan, efikasi diri dan motivasi akan mempengaruhi minat berwirausaha peserta didik, sehingga pendidikan kewirausahaan di sekolah, efikasi diri dan motivasi peserta didik harus selalu ditingkatkan.

Berdasarkan hasil penelitian tersebut peneliti merekomendasikan beberapa hal penting 1) bagi siswa, perlu untuk terus mengikuti pendidikan kewirausahaan dengan baik mengasah serta mengembangkan efikasi diri dan motivasi dengan mengikuti pelatihan-pelatihan berkaitan dengan efikasi diri dan motivasi dalam bidang kewirausahaan agar meningkatkan minat berwirausaha sehingga bisa menjadi seorang wirausaha yang sukses. 2) bagi sekolah, terus menjalankan dan mengevaluasi pendidikan kewirausahan dengan baik sesuai dengan kurikulum pendidikan kewirausahaan yang berlaku agar tujuan dari pendidikan kewirausahaan dapat tercapai dengan baik. 3) bagi pemerintah, perlu adanya upa yang langkah nyata dalam mendukung pelaksanaan pendidikan kewirausahaan seperti memberikan program-program pelatihan dan magang dalam bidang wirausaha bagi siswa.

\section{DAFTAR PUSTAKa}

Adekiya, A. A., \& Ibrahim, F. (2016). Entrepreneurship intention among students. The antecedent role of culture and entrepreneurship training and development. International Journal of Management Education, 14(2), 116-132. https://doi.org/10.1016/j.ijme.2016.03.001.

Andjarwati, T. (2015). Motivasi dari Sudut Pandang Teori Hirarki Kebutuhan Maslow, Teori Dua Faktor Herzberg, Teori xy Mc Gregor, dan Teori Motivasi Prestasi Mc Clelland. Jurnal Ilmu. Ekonomi Dan Manajemen, 1(1), 45-54. Retrieved from http://jurnal.untagsby.ac.id/index.php/jmm17/article/view/422

Armstrong, S. J. (n.d.). Educational Psychology: An International Journal of Experimental Educational Psychology The Influence of Individual Cognitive Style on Performance in Management Education. (October 2014), 37-41. https://doi.org/10.1080/014434100750018020

Ayu, D., Anggraeni, L., \& Nurcaya, I. N. (2016). Pendidikan Kewirausahaan Terhadap Niat . 5(4), 24242453.

Bandura, A. (2006). Toward a Psychology of Human Agency. Perspectives on Psychological Science, 1(2), 164-180. https://doi.org/10.1111/j.1745-6916.2006.00011.x

Bandura, A. (2010). Self-efficacy -Bandura. The Corsini Encyclopedia of Psychology, 1-3. 
https://doi.org/10, 9780470479216.

Business, S. (2015). Undergraduate students 'entrepreneurial intention: born or made? Kim Hoe Looi * Catheryn Khoo-Lattimore. 26(1).

Carree, M. A., \& Thurik, A. R. (2010). The Impact of Entrepreneurship on Economic Growth. https://doi.org/10.1007/978-1-4419-1191-9.

Che, S., Mistima, S., \& Mohd, N. (2015). Identifying Factors that Affecting the Entrepreneurial Intention among Engineering Technology Students. 211(September), 1016-1022. https://doi.org/10.1016/j.sbspro.2015.11.135.

Darmastuti, D. (2012). Implementasi Metode Simple Additive Weighting ( SAW ) Dalam Sistem Informasi Lowongan Kerja Berbasis Web. Jurnal Sistem Dan Teknologi Informasi, 16(2), 1-6. Retrieved from http://jurnal.untan.ac.id/index.php/justin/article/view/2658.

Denanyoh, R., Adjei, K., \& Nyemekye, G. E. (2015). Factors That Impact on Entrepreneurial Intention of Tertiary Students in Ghana. Factors That Impact on Entrepreneurial Intention of Tertiary Students in Ghana, 5(3), 19-29. https://doi.org/10.18533/ijbsr.v5i3.693.

Fayolle, A., \& Gailly, B. (2015). The impact of entrepreneurship education on entrepreneurial attitudes and intention: Hysteresis and persistence. Journal of Small Business Management, 53(1), 75-93. https://doi.org/10.1111/jsbm.12065.

Firdaus, N. (2014). Poverty Alleviation Through Social Entrepreneurship Approach. Jurnal Ekonomi Dan Pembangunan, 22(1), 55.

Indriyatni, L. (2013). Dalam Menumbuhkan Minat Mahasiswa Untuk Berwirausaha (Studi Kasus pada Mahasiswa STIE PELITA NUSANTARA SEMARANG ) Lies Indriyatni *). Fokus Ekonomi, $8(1), 52-59$.

Ismail, K., Anuar, M. A., Omar, W. Z. W., Aziz, A. A., Seohod, K., \& Akhtar, C. S. (2015). Entrepreneurial Intention, Entrepreneurial Orientation of Faculty and Students towards Commercialization. Procedia - Social and Behavioral Sciences, 181, 349-355. https://doi.org/10.1016/j.sbspro.2015.04.897.

Keputusan, D., Dengan, B., \& Dewi, S. N. (2017). LINGKUNGAN SOSIAL DAN PENDIDIKAN FORMAL. 5(1), 109-116.

Lazaric, N., \& Raybaut, A. (2014). Do incentive systems spur work motivation of inventors in high tech firms? A group-based perspective. 135-157. https://doi.org/10.1007/s00191-013-0336-2.

Lumpkin, G. T., Steier, L., \& Wright, M. (2011). in Family Business Business and Strategic. Strategic Entrepreneurship Journal, 306(2007), 285-306. https://doi.org/10.1002/sej.

Mahesa, A. D., \& Rahardja, E. (2012). Analisis Faktor-Faktor Motivasi Yang Mempengaruhi Minat Berwirausaha. Diponegoro Journal of Management, 1(4), 130-137. Retrieved from http://www.ejournal-s1.undip.ac.id/index.php/djom/article/view/787.

Moraes, G. H. S. M. de, Iizuka, E. S., \& Pedro, M. (2018). Effects of Entrepreneurial Characteristics and University Environment on Entrepreneurial Intention. Revista de Administração Contemporânea, 22(2), 226-248. https://doi.org/10.1590/1982-7849rac2018170133.

O'Gorman, C., Byrne, O., \& Pandya, D. (2008). How scientists commercialise new knowledge via entrepreneurship. Journal of Technology Transfer, 33(1), 23-43. https://doi.org/10.1007/s10961-0069010-2. 
Rachmadyanti, P., \& Wicaksono, V. D. (2017). Prosiding Seminar Nasional Inovasi Pendidikan Inovasi Pembelajaran Berbasis Karakter dalam Menghadapi Masyarakat Ekonomi ASEAN PENDIDIKAN KEWIRAUSAHAAN BAGI ANAK USIA SEKOLAH DASAR. Prosiding Seminar Nasional Inovasi Pendidikan Inovasi Pembelajaran Berbasis Karakter Dalam Menghadapi Masyarakat Ekonomi ASEAN, 419-437.

Schweizer, R., Vahlne, J. E., \& Johanson, J. (2010). Internationalization as an entrepreneurial process. Journal of International Entrepreneurship, 8(4), 343-370. https://doi.org/10.1007/s10843-010-0064-8.

Shinnar, R., Pruett, M., \& Toney, B. (2009). Entrepreneurship Education: Attitudes Across Campus. Journal of Education for Business, 84(3), 151-159. https://doi.org/10.3200/JOEB.84.3.151-159.

Wang, C. K., \& Wong, P. K. (2004). Entrepreneurial interest of university students in Singapore. Technovation, 24(2), 163-172. https://doi.org/10.1016/S0166-4972(02)00016-0.

Wedayanti, N., \& Giantari, I. (2016). Peran Pendidikan Kewirausahaan Dalam Memediasi Pengaruh Norma Subyektif Terhadap Niat Berwirausaha. E-Jurnal Manajemen Universitas Udayana, 5(1), 255039.

Y. A. Samuel., K. Ernest., J. B. A. (2013). An essessment of Entrepreneurship intention among Sunyani Polytechnic Marketing students. International Review of Management and Marketing, 3(1), 37-49.

Zimmerman, B. J. (2000). Self-Efficacy: An Essential Motive to Learn. Contemporary Educational Psychology, 25(1), 82-91. https://doi.org/10.1006/ceps.1999.1016 